\title{
STUDIES ON POLYETHERIN A. I ISOLATION AND CHARACTERIZATION
}

\author{
Jun-ichi Shoji, Shuichi Kozuki, Sigeru Matsutani, \\ Tokuo Kubota, Haruo Nishimura, Mikao Mayama, \\ Kiyoshi Motokawa, ye Tanaka, Noboru Shimaoka \\ and Hideo O'Tsuka
}

Shionogi Research Laboratory, Shionogi \& Co., Ltd., Fukushima-ku, Osaka, Japan

(Received for publication April 18, 1968)

\begin{abstract}
A new antibiotic polyetherin A was isolated from cultures of Streptomyces hygroscopicus strain E-749. The antibiotic is active against Gram positive bacteria including mycobacteria, and phytopathogenic fungi. The substance is obtained as colorless needles, m. p. $183.5 \sim 185^{\circ} \mathrm{C}$, and is a lipophilic acid with the molecular formula $\mathrm{C}_{42 \sim 43} \mathrm{H}_{72 \sim 74} \mathrm{O}_{12}$. It is dextrorotatory active and has no absorption in the ultraviolet and visible regions. The infrared and n.m.r. spectra of the antibiotic and some derivatives revealed a carboxyl, a methoxyl and two vicinal hydroxyl groups but no carbonyl function. This information suggested polycyclic polyether structure for the antibiotic.
\end{abstract}

In the course of a systematic screening for new antibiotics, a strain E-749, which was identified as Streptomyces hydroscopicus WAKSMAN et HENRICr 1948, was found to produce three antibiotics. The main product was named polyetherin A because of the structural features suggested from the present studies. Another product which is a water-soluble basic antibiotic active against gram positive and negative bacteria, will be described in a separate paper.

Polyetherin A was extracted with organic solvents from the mycelium and filtrate of cultures of the strain. The extract containing the antibiotic in free acid form was treated with $n$-hexane to remove insoluble impurities. Then it was converted to the sodium salt followed by treatment with $n$-hexane to precipitate the sodium salt as a crystalline powder. Further purification was achieved by column chromatography on silica gel with chloroform-methanol and/or recrystallization with various solvents. A minor product tentatively designated as component $B$, was also contained in the solvent extract, but was easily removed from polyetherin A during the above purification process. The homogeneity of purified polyetherin $A$ was confirmed by three kinds of thin-layer chromatography with a single entity shown in each of three systems.

The antibiotic is mainly active against gram-positive bacteria, mycobacteria and phytopathogenic fungi (Table 4). $\mathrm{LD}_{50}$ value of $10 \sim 15 \mathrm{mg} / \mathrm{kg}$ (mouse, i. p.) was observed.

Polyetherin A, colorless needles, m. p. $183.5 \sim 185.0^{\circ} \mathrm{C}$ sintering at $181^{\circ} \mathrm{C}$, is soluble in alcohols, acetone, ethyl acetate, chloroform, benzene and ether, slightly soluble in saturated hydrocarbons, and insoluble in water. Its lipophilic and hydrophobic nature 
Fig. 1. Infrared absorption spectra

(a) Polyetherin A free acid (Chloroform)

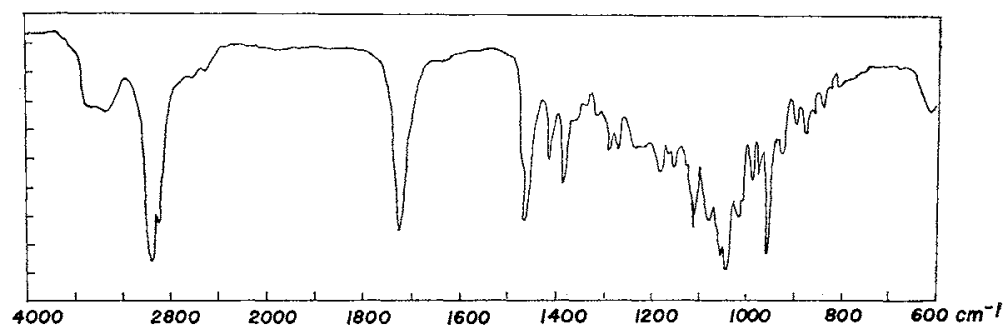

(b) Polyetherin A sodium salt (Chloroform)

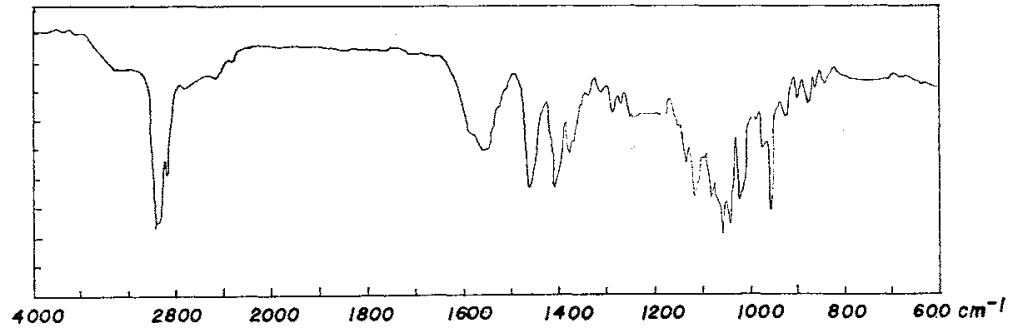

(c) Polyetherin A methyl ester monoacetonide (Nujol)

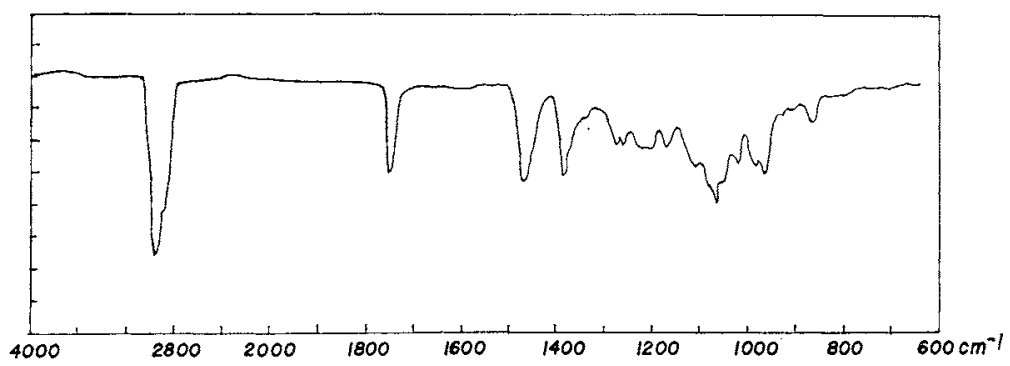

is shown even by the sodium salt which is soluble in chloroform and insoluble in water. This agrees with the unusual behaviour demonstrated in so-called " $\mathrm{pH}$ chromatograms" ${ }^{1)}$ (see experimental section). The antibiotic is optically active, $[\alpha]_{\mathrm{D}}^{24}$ $+36.2^{\circ} \pm 0.9^{\circ}$ (c $\left.0.842, \mathrm{CHCl}_{3}\right)$.

A molecular formula $\mathrm{C}_{42 \sim 43} \mathrm{H}_{72 \sim 74} \mathrm{O}_{12}(768 \sim 782)$ was indicated from repeated elemental analyses. The molecular size was confirmed by potentiomeric titration.

No absorption was observed in methanol solution (approximately $100 \mathrm{mcg} / \mathrm{ml}$ ) at $220 \sim 750 \mathrm{~m} \mu$. This indicated that there is neither an aromatic ring nor conjugated unsaturated system in the antibiotic molecule.

In the inf rared spectrum* (Fig. 1), an absorption band at $1,722 \mathrm{~cm}^{-1}$ for the free acid shif ted to a broad absorption at $1,555 \mathrm{~cm}^{-1}$ for the sodium salt, indicating the presence of a carboxyl group. Further, no other absorption observed at $1,800 \sim 1,500 \mathrm{~cm}^{-1}$ indicated the absence of carbonyl functions other than the carboxyl group. The presence of a single carboxyl group was deduced from the equivalence of molecular weight and. equivalent weight. Methylation with diazomethane gave polyetherin A methyl ester.

A broad absorption band at approximately $3,600 \sim 3,200 \mathrm{~cm}^{-1}$ observed in the

* Infrared absorption spectra were recorded with a Nihon Bunko Model DS-201B spectrophotometer. 
infrared spectra of the sodium salt and the methyl ester indicated the presence of hydroxyl groups. Acetylation of the methyl ester with acetic anhydride in pyridine afforded monoacetylpolyetherin A methyl ester. Reaction with acetone catalyzed by $p$-toluenesulfonic acid gave the methyl ester monoacetonide. The absorption attributable to hydroxyl groups did not disappear in the infrared spectrum of monoacetylpolyetherin A methyl ester, whose n.m.r. spectrum* also showed a signal probably attributable to a hydroxyl proton (1.34 ppm) which disappeared by shaking with deuterium oxide (Fig. 2). However, hydroxyl absorption completely disappeared from the infrared spectrum of the methyl ester monoacetonide (Fig. 1). These observations indicated two vicinal hydroxyl groups in the antibiotic molecule. One of them was resistant to acetylation, suggesting it has a tertiary nature.

One methoxyl group found by Zeisels' method was shown also by the n. m.r. spectrum of monoacetylpolyetherin A methyl ester (Fig. 2), where the peak areas of methyl protons of a methoxyl (3.32 ppm), a methyl ester (3.7I ppm), and an acetyl (2.1 ppm) were comparable to each other.

Information obtained up to now indicated a carboxyl, a methoxyl and two hydroxyl groups as oxygen function, and no carbonyl function. Therefore, the remaining seven oxygens out of the twelve in the molecular formula were considered to exist as ether linkages. Several intense absorptions at $1,117 \sim 1,045 \mathrm{~cm}^{-1}$ in the infrared spectrum of the antibiotic supported this conclusion.

Polyetherin A did not decolorize potassium permanganate and bromine in aqueous methanol solutions. The negative reactions and no sharp signal observed at $8.0 \sim 4.5$ ppm in the n.m.r. spectrum suggested the absence of a double bond in the antibiotic molecule. Thus, the structure must contain five or six rings.

From these considerations, polyetherin A was characterized as a polycyclic polyether compound with a carboxyl, a methoxyl and two vicinal hydroxyl groups, possibly similar to the structure of monensic acid $^{2)}$ which has been elucidated by $\mathrm{X}$-ray diff raction analysis.

** N. m. r. spectra were taken with a Varian-A 60 spectrometer on solutions in deuterochloroform containing trimethylsilan as an internal reference at normal probe temperature. Calibration of the spectrometer was checked by the usual side-band technique. 
Polyetherin A was compared with nigericin ${ }^{3}$, antibiotic $X-206, X-469^{4}$ and monensic acid, and found to be different.

\section{Experimental}

Taxonomic Studies on Polyetherin A-producing Strain: The strain E-749 which pro* duces a new antibiotic, polyetherin $A$, was isolated from a soil sample collected at Amagasaki City of Hyogo Prefecture in 1963. Morphological, cultural and physiological characteristics of the strain were studied and the results were described below:

(a) Morphological characteristics. The microorganisms were incubated on each medium at $28^{\circ} \mathrm{C}$ for 14 days. The morphological properties were observed on Bennetr's agar medium and detailed observations were made with the agar-cylinder culture method ${ }^{5)}$. The structure of spore surface was observed with electron microscope. Aerial mycelium is formed abundantly on BENNETT's agar and looked powdery to velvety macroscopically. The sporophores are formed on aerial mycelium arising as short side branches from the main stem and their forms are mostly tight spirals, occasionally loops and hooks. The spores are formed in chains and the shape of spore is oval to short cylindrical $(0.9$ to $1.0 \mu$ in width, 1.0 to $1.5 \mu$ in length). The surface of the spore is smooth. Sporangium and flagellated spore are not observed and also fragmentation and sclerotia in substrate mycelium are not observed. (b) Cultural and physiological characteristics of the strain are given in Tables 1 and 2. Utilization of carbon sources by the strain on PRIDHAM-Gotilieb's basal agar medium is summarized in Table 3.

From the above results, the strain E-749 belongs to genus Streptomyces and the characteristics will be summarized as follows: (1) The aerial mycelium exhibits the characteristic

Table 1. Cultural characteristics of the strain E-749*

\begin{tabular}{|c|c|c|c|c|}
\hline Medium & Growth & Aerial mycelium & $\begin{array}{l}\text { Substrate mycelium } \\
\quad \text { (Reverse) }\end{array}$ & $\begin{array}{l}\text { Soluble } \\
\text { pigment }\end{array}$ \\
\hline $\begin{array}{l}\text { CzAPEK's } \\
\text { agar }\end{array}$ & Good & $\begin{array}{l}\text { Abundant, early brownish white, later } \\
\text { brownish gray }\end{array}$ & Pale yellowish brown & None \\
\hline $\begin{array}{l}\text { Glucose- } \\
\text { asparagine } \\
\text { agar }\end{array}$ & Good & $\begin{array}{l}\text { Abundant, early brownish white, later } \\
\text { brownish gray }\end{array}$ & Pale yellowish brown & None \\
\hline Starch agar & Good & $\begin{array}{l}\text { Abundant, early brownish white, later } \\
\text { dark brownish gray }\end{array}$ & Brownish gray & None \\
\hline $\begin{array}{l}\text { Cellulose } \\
\text { agar }\end{array}$ & Scant & No aerial mycelium & Brownish gray & None \\
\hline $\begin{array}{l}\text { BENNETT'S } \\
\text { agar }\end{array}$ & Good & $\begin{array}{l}\text { Abundant, early brownish white to } \\
\text { brownish gray, later becomes moist } \\
\text { and exhibits brownish black patches, } \\
\text { gradually spreading over the whole } \\
\text { surface. }\end{array}$ & Pale yellowish brown & None \\
\hline $\begin{array}{l}\text { Nutrient } \\
\text { agar }\end{array}$ & Fair & No aerial mycelium & Pale yellowish brown & None \\
\hline $\begin{array}{l}\text { Glucose- } \\
\text { bouillon } \\
\text { agar }\end{array}$ & Good & Fair, white & Yellowish brown & None \\
\hline Potato plug & Good & Fair, white & Pale yellowish brown & None \\
\hline Skim milk & Good & Scant & Pale yellowish brown & None \\
\hline $\begin{array}{l}\text { Gelatin } \\
\text { medium }\end{array}$ & $\begin{array}{l}\text { Poor to } \\
\text { fair }\end{array}$ & Poor, brownish white & Light brownish gray & None \\
\hline
\end{tabular}

Growth type in glucose-bouillon medium : Bottom type.

Growth response to temperature (BENNETr's agar, 10 days incubation): Good growth at $28^{\circ} \mathrm{C}$, fair growth at $27^{\circ} \mathrm{C}$, scant growth at $45^{\circ} \mathrm{C}$.

* All cultures were incubated at $28^{\circ} \mathrm{C}$ for 14 days except the test of growth response to temperature. 
Table 2. Physiological characteristics of the strain E-749*

\begin{tabular}{l|l}
\hline \multicolumn{1}{c|}{ Property } & \multicolumn{1}{c}{ Result } \\
\hline Production of melanoid pigment & Negative \\
Tyrosinase reaction & Negative \\
Acid formation from glucose & Negative \\
Nitrate reduction & Positive \\
Starch hydrolysis & Positive \\
Gelatin liquefaction & Positive, strong \\
Milk peptonization & Positive \\
Cellulose reaction & Negative \\
\hline
\end{tabular}

* All cultures were incubated at $28^{\circ} \mathrm{C}$ for 14 days.

moist, glistening, dark hydroscopic patches, gradually spreading over the whole surface on BENNETT's agar medium. (2) The sporophores are mostly tight spirals, occasionally loops and hooks and the surface of spore is smooth. (3) The color of aerial mycelium is brownish gray on almost media and no soluble pigment on almost media. (4) The melanoid pigment is not produced and also tyrosinase reaction is negative. (5) Acid formation from glucose is negative. (6) Growth type on glucose broth is bottom type. (7) Optimal growth temperature is $28^{\circ} \mathrm{C}$. (8) Liquefaction of gelatin is positive.

Among the known species of Streptomyces described in Bergey's manual of determinative bacteriology, 1957, 7Ed. ${ }^{6)}$, Waksman's The actinomycetes, 1961 Vol. $2^{7)}$, TREAsNer and BACKUS ${ }^{8)}$ and other literatures the characteristics of the strain E-749 were identical to those of Streptomyces hygroscopicus Waksman et Henrici 1948 ${ }^{5}$ in fundamental characteristics, i.e. hygroscopic feature of aerial mycelium, sporophores terminate in tight spirals of many turns, brownish gray aerial mycelium on almost media, no production of melanoid pigment, and positive peptonization of milk and liquefaction of gelatin. Thus, the strain E-749 was named Streptomyces hygroscopicus E-749.

Fermentation of a Streptomyces Strain E-749: The strain was shake-cultured for 48 hours at $27^{\circ} \mathrm{C}$ with a medium consisting of glucose $1.0 \%$, peptone $0.5 \%$, meat extract $0.5 \%$, sodium chloride $0.3 \%$, and calcium carbonate $0.3 \%, \mathrm{pH} 7.0$. A $450-\mathrm{ml}$ portion of the culture was then transferred into a 30-liter jar fermentor containing 20 liters of a fermentation medium whose ingredients were $\operatorname{starch} 1.0 \%$, glycerine $0.5 \%$, soy bean meal $1.0 \%$, corn steep liquor $0.5 \%$, yeast extract $0.01 \%$, sodium chloride $0.3 \%$, and calcium carbonate $0.3 \%, \mathrm{pH} 7.0$. Fermentation was carried out for 96 hours at $27^{\circ} \mathrm{C}$ under agitation of 200 r. p. m. and aeration of 20 liters per minute. Production of polyetherin A was approximately $100 \mathrm{mcg} / \mathrm{ml}$ as an average of several fermentations.

Isolation of Polyetherin A: Sixty liters of the above cultured broth were filtered with Celite $(600 \mathrm{~g})$ at $\mathrm{pH} 3.0$. The filtrate was extracted with chloroform (6 liters). The mycelial cake was extracted with methanol (3 liters) twice. The methanol extracts were then concentrated, and the active substance was transferred into chloroform. The chloroform solutions from the filtrate and the mycelial cake were then combined, washed with water, dried with anhydrous sodium sulfate, and concentrated to an oily material. This concentrate was then extracted with $n$-hexane to remove an insoluble residue. After evaporation of the $n$-hexane, the resulting syrup was dissolved in chloroform, which was then shaken with dilute sodium hydroxide to convert polyetherin $\mathrm{A}$ free acid into its 
sodium salt. The chloroform solution was again dried and concentrated. Addition of $n-$ hexane to the concentrate resulted in precipitation of polyetherin A sodium salt $(4.5 \mathrm{~g})$ as a crystalline powder.

In some cases, a crystalline material was not obtained, but only an oily substance was produced by the above procedure. In such cases, purification was effected by column chromatography on silica gel (Merck, $0.2 \sim 0.5 \mathrm{~mm}$ ) with a mixture of chloroform and methanol, the methanol concentration of which increased over a 0 to $5 \%$ gradient.

Repeated recrystallization from methanol-water afforded colorless needles of polyetherin A sodium salt, m. p.* $245 \sim 255^{\circ} \mathrm{C}$ (dec.).

$$
\begin{array}{llll}
\text { Anal. Found : } & \text { C } 64.19,64.25 ; & \mathrm{H} \mathrm{9.18,9.11;} & \mathrm{Na} 3.74,3.27 \\
\text { Calcd. for } \mathrm{C}_{42} \mathrm{H}_{71} \mathrm{O}_{12} \mathrm{Na}: & \text { C } 63.80 ; & \mathrm{H} 8.99 ; & \mathrm{Na} 2.91 \\
\text { Calcd. for } \mathrm{C}_{43} \mathrm{H}_{73} \mathrm{O}_{12} \mathrm{Na}: \text { C } 64.18 ; & \mathrm{H} \mathrm{9.01;} & \mathrm{Na} 2.86 \% .
\end{array}
$$

Shaking a chloroform solution of the sodium salt with dilute hydrochloric acid followed by recrystallization from methanol-water gave polyetherin $A$ free acid as colorless needles, m. p. $183.5 \sim 185.0^{\circ} \mathrm{C}$ (sintering at $181^{\circ} \mathrm{C}$ ).

Anal. Found : C 65.39, 65.86; H 9.45, 9.36; O 24.48, 23.62; $\mathrm{OCH}_{3} 4.70,4.61$; MW (Osmometry, chloroform) 728, 827.

Calcd. for $\mathrm{C}_{41} \mathrm{H}_{70} \mathrm{O}_{12}$ : $\quad$ C 65.25; H 9.28; O 25.64; MW 754 .

Calcd. for $\mathrm{C}_{41} \mathrm{H}_{69} \mathrm{O}_{11}\left(\mathrm{OCH}_{3}\right): \mathrm{C} 65.59 ; \mathrm{H} 9.44 ; \mathrm{O} 24.97 ; \mathrm{OCH}_{3} 4.04 ; \mathrm{MW} 768$.

Calcd. for $\mathrm{C}_{43} \mathrm{H}_{74} \mathrm{O}_{12}$ : C 65.98; H 9.46; O 24.62; MW 782 .

$[\alpha]_{\mathrm{D}}^{24}+36.2 \pm 0.9^{\circ}$ (c, 0.842, chloroform), $+10.1 \pm 0.2^{\circ}$ (c, 2.124, methano1).

"pH-Chromatograms" of Polyetherin A and a Minor Component: When polyetherin A was chromatographed by the technique of so-called " $\mathrm{pH}$-chromatograms"1), a straight line moving to the top was observed (Fig. 3). Though various solvents were tried, an S-shaped curve was not obtained, the antibiotic behaving like a nonelectrolyte. Thus, "pH-chromatograms" are not always useful to determine the ionic character of unknown antibiotics.

In the crude preparation, i.e., the chloroform extract of the culture broth, a minor component was also detected at the origin of the chromatogram (Fig. 3). B), which was active against $B$. subtilis but not Piricularia oryzae, was isolated by cellulose column chromatography but not completely purified.

Thin-Layer Chromatograph: Three kinds of thin-layer chromatograms visualized by sulfuric acid were utilized in order to check the purity of the samples. Polyetherin A gave the following $\operatorname{Rf}$ values with considerable deviation: $\operatorname{Rf} 0.44 \sim 0.60$ on silica gel $G$ with chloroform-methanol $(9: 1)$, Rf $0.40 \sim 0.46$ on silica gel $G$ with benzene-ethyl acetate methanol $(6: 4: 1)$, and $\operatorname{Rf} 0.33 \sim 0.48$ on aluminum oxide with a lower phase of ethyl acetate - tetrachloroethane - water $(3: 1: 3)$.

Antimicrobial Activity: The usual agar dilution technique was employed for bacteria and fungi, and the broth dilution technique for tuberculosis bacilli. The minimal inhibitory concentrations observed are listed in Table 4 .

Potentiometric Titration: (a) One hundred and fifty $\mathrm{mg}$ of polyetherin A free acid dissolved in a mixture of methanol $(14 \mathrm{ml})$ and water $(5 \mathrm{ml})$ were titrated with $0.1 \mathrm{~N} \mathrm{NaOH}$ using an automatic titrater (Multi-Dosimat $\mathrm{E} \mathrm{415)}$ with intervals of $0.05 \mathrm{ml}$, and $\mathrm{pHs}$ were measured by a Radiometer pH-meter. A sharp titration curve was plotted, in which $1.956 \mathrm{~m}$ moles of $\mathrm{NaOH}$ was consumed at the neutralization point and $\mathrm{pH} 6.98$ at a half neutralization point was observed. From this, an equivalent weight of 767 for the acid was calculated. (b) Polyetherin A sodium salt $(151.00 \mathrm{mg}$ ) was similarly titrated with $0.1 \mathrm{~N}$

\footnotetext{
* All melting points were uncorrected and were determined using a micro melting point apparatus.
} 
Table 4. Antimicrobial spectrum of polyetherin A

\begin{tabular}{|c|c|c|}
\hline & Test organism & $\begin{array}{l}\text { M. I. C. } \\
(\mathrm{mcg} / \mathrm{ml})\end{array}$ \\
\hline $\begin{array}{l}\text { Nutrient agar, } \\
37^{\circ} \mathrm{C}, 18 \text { hours }\end{array}$ & $\begin{array}{l}\text { Shigella dysenteriae } \\
\text { Salmonella typhosa } \\
\text { Escherichia coli, Umezawa } \\
\text { Pseudomonas aeruginosa } \\
\text { Klebsiella pneumoniae } \\
\text { Bacillus subtilis, PCI--219 } \\
\text { Bacillus anthracis } \\
\text { Staphylococcus aureus, FDA } 209 \mathrm{P} \\
\text { Sarcina lutea, PCI-1001 }\end{array}$ & $\begin{aligned}> & 50 \\
> & 50 \\
> & 50 \\
> & 50 \\
> & 50 \\
& 1.0 \\
& 0.5 \\
& 0.5 \\
& 0.5\end{aligned}$ \\
\hline $\begin{array}{l}\text { Blood agar, } \\
37^{\circ} \mathrm{C}, 18 \text { hours }\end{array}$ & $\begin{array}{l}\text { Diplococcus pneumoniae, Type I } \\
\text { Streptococcus hemolyticus, Denken } \\
\text { Corynebacterium diphtheriae, Tront } \\
\text { Staphylococcus aureus, FDA } 209 \mathrm{P}\end{array}$ & $\begin{array}{l}0.5 \\
1.0 \\
1.0 \\
1.0\end{array}$ \\
\hline $\begin{array}{l}4 \% \text { Glycerin } \\
\text { agar, } 37^{\circ} \mathrm{C}, \\
4 \text { days }\end{array}$ & $\begin{array}{l}\text { Mycobacterium } 607 \\
\text { Mycobacterium phlei } \\
\text { Mycobacterium smegmatis } \\
\text { Mycobacterium avium }\end{array}$ & $\begin{array}{l}5.0 \\
2.0 \\
5.0 \\
2.0\end{array}$ \\
\hline $\begin{array}{l}\text { KIRCHNER's } \\
\text { broth } \\
\text { containing } 10 \% \\
\text { human plasma, } \\
37^{\circ} \mathrm{C}, 21 \text { days }\end{array}$ & Mycobacterium tuberculosis, $\mathrm{H}_{37} \mathrm{Rv}$ & 5.0 \\
\hline $\begin{array}{l}\text { Potato-glucose } \\
\text { agar, } 28^{\circ} \mathrm{C} \text {, } \\
7 \text { days }\end{array}$ & $\begin{array}{l}\text { Piricularia oryzae } \\
\text { Colletotrichum sp. } \\
\text { Phytophora infestans } \\
\text { Corticium sasakii } \\
\text { Cochliobolus miyabeanus } \\
\text { Fusarium oxysporum } \\
\text { Sclerotinia libertiana } \\
\text { Alternaria kikuchiana }\end{array}$ & $\begin{array}{r}0.8 \\
3.2 \\
>100 \\
>100 \\
1.6 \\
>100 \\
6.3 \\
>100 \\
\end{array}$ \\
\hline $\begin{array}{l}\text { SaBOURAUD } \\
\text { glucose agar, } \\
28^{\circ} \mathrm{C}, 7 \text { days }\end{array}$ & $\begin{array}{l}\text { Trichophyton mentagrophytes } \\
\text { Trichophyton rubrum } \\
\text { Trichophyton purpureum } \\
\text { Trichophyton ferrugineum } \\
\text { Epidermophyton floccosum } \\
\text { Microsporum gypseum } \\
\text { Aspergillus niger } \\
\text { Candida albicans } \\
\text { Cryptococcus neoformans } \\
\text { Saccharomyces cerevisiae }\end{array}$ & $\begin{aligned} &> 100 \\
&> 100 \\
&> 100 \\
&> 100 \\
& 25 \\
&> 100 \\
&> 100 \\
& 12.5 \\
&>100 \\
& 12.5\end{aligned}$ \\
\hline
\end{tabular}

HCl. An equivalent weight of 777 for the sodium salt was found.

Polyetherin A Methyl Ester: To a suspension of polyetherin $\mathrm{A}$ free acid ( $151.5 \mathrm{mg})$ in ether (10 $\mathrm{ml}$ ), an ethereal diazomethane solution was added with chilling by ice and the mixture was allowed to stand for 1.5 hours. After decomposition of excess diazomethane with acetic acid, the reaction mixture was washed with sodium bicarbonate solution and subsequently with water, followed by drying with anhydrous sodium sulfate. Evaporation of the solvent afforded polyetherin A methyl ester ( $157.5 \mathrm{mg}$ ) in a foam-like state.

IR chloroform: 1,730, 1,155 $\mathrm{cm}^{-1}\left(-\mathrm{CO}_{2} \mathrm{CH}_{3}\right), 3,600 \sim$ $3,200 \mathrm{~cm}^{-1}(-\mathrm{OH})$.

N.m.r. : $\quad-\mathrm{CO}_{2} \mathrm{CH}_{3}, 3.71 \mathrm{ppm}$ $3 \mathrm{H} ;-\mathrm{OCH}_{3}, 3.30 \mathrm{ppm} 3 \mathrm{H}$.

Monoacetylpolyetherin A Methyl Ester: The methyl ester (101 mg) obtained as above was dissolved in a mixture of pyridine $(2 \mathrm{ml})$ and acetic anhydride $(1 \mathrm{ml})$, and the solution left overnight at room temperature. Ice water was added to the reaction mixture followed by ether extraction. The ether layer was washed with dilute hydrochloric acid, sodium bicarbonate solution and water consecutively. After drying with anhydrous sodium sulfate, evaporation of the solvent gave the monoacetyl derivative as an amorphous powder.

IR (Nujol): $1,745,1,160 \mathrm{~cm}^{-1}\left(-\mathrm{CO}_{2} \mathrm{CH}_{3},-\mathrm{OCOCH}_{3}\right), 3,580,3,200 \mathrm{~cm}^{-1}(-\mathrm{OH})$.

N.m.r.: $-\mathrm{CO}_{2} \mathrm{CH}_{3}, 3.71 \mathrm{ppm} 3 \mathrm{H} ;-\mathrm{OCOCH}_{3} 2.1 \mathrm{ppm} 3 \mathrm{H} ;-\mathrm{OCH}_{3} 3.32 \mathrm{ppm} 3 \mathrm{H}$.

Polyetherin A Methyl Ester Monoacetonide: The methyl ester (100 mg) and p-toluenesulfonic acid $(17 \mathrm{mg})$ was dissolved in acetone $(9 \mathrm{ml})$ and allowed to stand for 18 hours at room temperature. Then the reaction mixture was neutralized with $10 \%$ sodium bicarbonate solution and concentrated under reduced pressure. The concentrate was extracted with ether after addition of water, and the extract was washed with sodium bicarbonate solution and water, followed by drying with anhydrous sodium sulfate. The methyl ester acetonide was obtained by solvent evaporation as a crude powder (100 mg). Purification was performed by preparative thin-layer chromatography on silica gel $G$ with 
toluene-ethylacetate $(3: 1)$. An Rf of approximately 0.31 was determined by ultraviolet light with a spray of $1 \%$ morin methanol solution. The purified sample of the methyl ester acetonide was obtained as an amorphous powder $(67.8 \mathrm{mg})$.

IR (Nujol): $1,742,1,170 \mathrm{~cm}^{-1}\left(-\mathrm{CO}_{2} \mathrm{CH}_{3}\right)$.

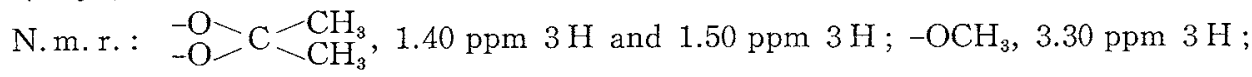
$-\mathrm{CO}_{2} \mathrm{CH}_{3}, 3.71 \mathrm{ppm} 3 \mathrm{H}$.

\section{References}

1) Betrina, V. : A paper chromatography method for the determination of suitable pH values for the extraction of antibiotics. Nature 182:796 797, 1958

2) Agtarap, A.; J. W. Chamberlin, M. Pinkerton \& L. Steinrajf : The structure of monensic acid, a new biologically active compound. J. Am. Chem. Soc. $89: 5737 \sim 5739,1967$.

3) HARNED, R. L.; P. H. Hidy, C. J. CORum \& K. L. Jones : Nigericin, a new crystalline antibiotic from an unidentified Streptomyces. Antibiot. \& Chemoth. 1:594 596, 1951

4) Berger, J.; A. I. Rachlin, W. E. Scotr, L. H. Sternbagh \& M. W. Goldpberg: The isolation of three new crystalline antibiotics from Streptomyces. J. Am. Chem. Soc. $73: 5295 \sim 5298,1951$

5) Nishimura, H. \& K. TaWara : A method for the microscopical observation of Streptomyces using agar-cylinder culture. J. Antibiotics, Ser. A $10: 227,1957$

6) BERGEY's Manual of determinative bacteriology. 7th Ed. 1957, Williams \& Wilkins Co.

7) WaKsman, S. A.: The actinomycetes. Vol. 2, pp. 230 231, 1961, The Williams \& Wilkins Co.

8) Tresner, H. D. \& E. J. Backus: A broadened concept of the characteristics of Streptomyces hygroscopicus. Appl. Microbiol. $4: 243 \sim 250,1956$ 